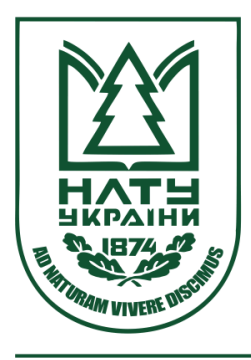

Науковий вісник НлтУ України Scientific Bulletin of UNFU

https://nv.nltu.edu.ua

https://doi.org/10.36930/40310404

$@ \bowtie$ Correspondence author

Article received 14.06.2021 p.

Article accepted 09.09.2021 p.

O. E. Ivanchenko

UDC 712.253:635.925(477.63-21)

В. П. Бессонова, О. Є. Іванченко

Дніпровський державний аграрно-економічний університет, м. Дніпро, Україна

\title{
ДИЗАЙНЕРСЬКІ РІШЕННЯ ТА ВИДОВИЙ СКЛАД РОСЛИН ПАРКУ СЕЛИЩА МІСЬКОГО ТИПУ ПЕТРИКІВКА ДНІПРОПЕТРОВСЬКОЇ ОБЛАСТІ
}

\begin{abstract}
Досліджено ландшафтну організацію парку смт Петриківка та наявний асортимент декоративних трав'янистих та деревно-кущових рослин, оцінено їхні таксаційні та життєві характеристики. Територія парку має виражену зональність і складається 3 дитячого майданчика, зони фізкультурно-оздоровчих та масових заходів і тихого відпочинку. У парку є елементи монументального декоративного мистецтва, такі як стела останньому кошовому отаману П. Калнишевському, малі архітектурні форми - усічена крашанка, садово-паркова скульптура - дівчинка-художниця, кований букет та гірлянда й інші елементи ландшафтного дизайну (сухий ставок). Квіткове оформлення парку представлене клумбами, міксбордерами, рабатками, стрічками. Асортимент квіткових рослин складається з одно- і багаторічних рослин: садові троянди, петунія гібридна, півники гібридні, канна індійська, седум видний, півонія китайська та ін. Використано й контейнерне озеленення 3 хризантемою корейською. 3 грунтопокривних рослин набули застосування різні види седумів та барвінок малий. 3 кущових рослин у парку зростають калина звичайна, спірея японська, барбарис Тунберга, вейгела квітуча, різні види ялівців, туї східна та західна, які утворюють групи або виступають як солітери. Всього у парку зростає 31 вид деревних і кущових рослин, що належать до 14 родин. Загальна їх кількість становить 251 шт. У деревних насадженнях переважає гіркокаштан звичайний (59,03 \% від усіх рослин). Кількісна представленість інших таксонів - 10 і менше екземплярів. За діаметром штамбу у насадженнях найрепрезентованішими є дерева, які належать до класів 24-28 та 28-32 см - 25,17 та 22,34 \% від їх загальної кількості. У цих групах переважає гіркокаштан звичайний, як найчисельніший у парку вид. Близько половини дерев парку мають висоту від 6,1 до 8,0 м. Менша висота (4,1-6,0 м) характерна 34,96 \% дерев. Без ознак ослаблення у парку смт Петриківка зростає 80,5\% деревної рослинності, 16,3 та 3,2 \% є помірно та середньо ослабленими. Загалом за індексом життєвого стану деревостан оцінюють як "здоровий".
\end{abstract}

Ключові слова: селищний парк; ландшафтний дизайн території; квіткове оформлення; деревні рослини; таксаційні характеристики; життєвий стан.

\section{Вступ / Introduction}

Парк - провідний компонент зелених насаджень у населених пунктах $[4,15]$. Значення парків у створенні оптимальних умов для життедіяльності та відпочинку жителів важко переоцінити. Виконуючи велику санітарно-гігієнічну та середовище-стабілізаційну роль, вони водночас виконують роль рекреаційних об'єктів [15, 27]. О. П. Суслова зі співавторами [43] наголошують на особливій ролі парків як прикладів побудови стійких довговічних насаджень та як осередків збереження фіторізноманіття.

Останніми роками в Україні мережа парків фактично не розвивається, спостерігається ії скорочення, регресія та занепад цих важливих об'єктів рекреації. В. О. Сисак та Л. М. Бармашина [45] зазначають, що відбувається скорочення базових паркових комплексів, а також міських і районних парків. Цю проблему необхідно вирішувати.

На сьогодні під час проєктування садово-паркових комплексів недостатньо створити нове місце відпочинку. Сучасні парки $\epsilon$ ще й освітньо-просвітницькими локаціями різної тематичної спрямованості [23]. Відбувається пошук нових споживчих ніш і відповідних форм організації середовища, які спрямовані на підвищення соціально-культурної якості й емоційно-естетичного рівня [24]. Особливу увагу потрібно приділяти створенню парків, що не тільки відтворюють атмосферу України, але й є самобутніми елементами національного фольклору. Цей напрям розвитку парків спрямований на розширення туристичного потенціалу територій [45]. За сучасними уявленнями створення таких об'єктів ландшафтної архітектури як виставкові сади і парки, експозиційні зони, значно підвищує рівень рекреаційного обслуговування. Вони базуються на пізнавальних та естетичних функціях [32]. Нині виникає потреба в побудові перспективних оптимальних моделей парків з урахуванням традицій українського народу, його менталітету та духовного розвитку [45]. Надзвичайно ілюстративною з цих позицій $є$ книга В. П. Кучерявого "Са-

Інформація про авторів:

Бессонова Валентина Петрівна, д-р біол. наук, професор, кафедра садово-паркового господарства.

Email: valentinabessonova492@gmail.com

Іванченко Ольга Євгенівна, канд. біол. наук, доцент, в.о. завідувача кафедри садово-паркового господарства. Email: ivanchenko_78@ukr.net

Цитування за ДСту: Бессонова В. П., Іванченко О. Є. Дизайнерські рішення та видовий склад рослин парку селища міського типу Петриківка Дніпропетровської області. Науковий вісник НЛтУ України. 2021, т. 31, № 4. С. 27-35.

Citation APA: Bessonova, V. P., \& Ivanchenko, O. E. (2021). Design solutions and species composition of plants of the park in Petrykivka urban-type settlement, Dnipropetrovsk region. Scientific Bulletin of UNFU, 31(4), 27-35. https://doi.org/10.36930/40310404

Науковий вісник НЛтУ України, 2021, т. 31, № $4 \quad$ Scientific Bulletin of UNFU, 2021, vol. 31, no 4 
ди і парки Львова" [28], в якій міститься багато інформації про історію створення парків Львова, описано особливості садово-паркового мистецтва та їх зелених насаджень

У парках необхідно хоча б у межах певного часу об'єднати людину з природою, історією, культурою, сформувати нове рекреаційне середовище [7]. Саме таким може стати парк смт Петриківка. Він хоча й не належить до спеціалізованих парків, але його можна певною мірою вважати пізнавально-тематичним, оскільки він у малих архітектурних формах ілюструє і пропагує Петриківський народний розпис - український декоративно-орнаментальний народний живопис, що сформувався у смт Петриківка, звідки й походить його назва. Вишуканий і неповторний, він становить гордість украінського народу. Цей парк потребує подальшого вдосконалення. Основою розроблення принципів реконструкції паркових насаджень повинні, передусім, слугувати ефективні методи оцінювання деревних рослин за їх життєвим станом, стійкістю в умовах зростання [13]. Сучасний стан паркової території є відправною точкою для моніторингу цього об'єкта.

Отже, актуальним завданням є визначення таксономічного складу, таксаційних характеристик та життєвого стану дендрофлори, особливостей дизайну парку смт Петриківка.

Об'єкт дослідження - особливості дизайну та озеленення парку смт Петриківка.

Предмет дослідження - таксономічні та таксаційні характеристики, життєвий стан дендрофлори, дизайнерські рішення парку смт Петриківка.

Мета роботи - проаналізувати ландшафтну структуру, таксономічні та таксаційні характеристики деревних насаджень парку смт Петриківка.

Для досягнення зазначеної мети визначено такі основні завдання дослідження:

- виявити особливості структури і дизайнерських рішень парку смт Петриківка;

- встановити таксономічний склад дендрофлори парку;

- визначити таксаційні показники та життєвий стан деревних насаджень;

- проаналізувати ключові ділянки квіткового оформлення.

Наукова новизна отриманих результатів дослідження - вперше досліджено дизайнерські рішення, видове різноманіття та таксаційні показники деревних рослин парку смт Петриківка Дніпропетровської області.

Практична значущість результатів дослідження отримані результати є основою для розроблення рекомендацій із реконструкції парку смт Петриківка, а також догляду за рослинами.

Аналіз останніх досліджень і публікацій. Парки великі комплекси оздоровчої, культурно-просвітницької і фізкультурної роботи. Важлива їх роль у вирішенні екологічних проблем і компенсації дефіциту природних компонентів $[15,33] .3$ огляду на це актуальним $\epsilon$ вивчення попиту населення на рекреаційні об'єкти, створення оптимальних умов для відпочинку $[1,34]$.

Одним із пріоритетних напрямів вивчення насаджень парків $\epsilon$ вирішення питань їх фітоценотичної структури [3, 6, 29, 38]. Р. Б. Дудин [12] зазначає, що дослідження фітоценотичної структури парків, коли розглядають життєвий стан, стійкість до екологічних чинників, може забезпечити розроблення науково обгрунтованих рекомендацій з реставрації, консервації та реконструкції паркових насаджень. Такої ж думки дотримується Ю. Р. Рамазанова [38].

У наукових дослідженнях, присвячених паркам, провідне місце належить аналізу видового складу деревних рослин $[6,10,16,31,42,44]$, що $є$ вкладом у вирішення питань біорізноманіття. Надають рекомендації 3 їх реконструкції [13] та підвищення декоративності і стійкості [30]. Аналізують фітомеліоративну роль зелених насаджень парків, їх фітонцидну роль, здатність до іонізації повітря [8, 26, 27].

Важливим питанням $є$ добір рослин для тих чи інших композицій. Добір найчастіше здійснюють за такими основними принципами: екологічний, фітоценотичний, систематичний, географічний та фізіономічний. Вибір принципу добору залежить від призначення насаджень. На об'єктах озеленення зазвичай використовують екологічний, під час створення великих зелених масивів - фітоценологічний, систематичний і географічний - для розміщення колекцій. Фізіономічний принцип враховують у будь-якому випадку [11].

Приділяють увагу обговоренню таких аспектів, як декоративність насаджень [19], потреба формування єдиного гармонійного ансамблю елементів живої природи й забудов, з урахуванням естетичної ролі крон, орнаментальності і кольору листя тощо $[10,18]$, надають естетичну оцінку насадженням парків [6, 16, 26, 27], ландшафтному дизайну [35].

Варто зазначити, що особливу зацікавленість має вивчення міських парків, тоді як аналіз насаджень та дизайну селищних парків України здійснено у невеликій кількості робіт [6, 16, 36, 39, 40, 42]. Особливо слабо вивчено це питання у південно-східному регіоні.

Під час створення селищних парків не завжди дотримуються основних зазначених вище положень їх конструювання, вимог і принципів добору рослин, що свідчить про потребу вивчення цих питань стосовно конкретного парку. Дуже важливим є аналіз видового складу, дизайнерських рішень та естетичного вигляду зелених насаджень, що буде підгрунтям для розроблення рекомендацій з реконструкції та моніторингу селищних парків.

Матеріали та методи дослідження. Географічні координати смт Петриківка - 48'43'33 пн.ш., 34'37'53 сх.д. Висота н.р.м. - 59 м. Водойма - річка Чаплинка. Першу згадку про селище датовано 20 лютим 1772 р. Історія Петриківки нерозривно пов'язана 3 діяльністю останнього кошового отамана П. І. Калнишевського. За Чаплинським бродом було засновано зимівник козака Петрика, що пізніше виріс у поселення Петриківка. 3 ініціативи Петра Калнишевського поселенцям стали відводитися землі вздовж річок Орілі і Проточі. До Петриківки було переведено управління Протовчанської паланки $з$ невеликим гарнізоном.

Парк має площу близько 2 га та межує 3 проспектом Калнишевського, вулицями Свободи та Європейською (рис. 1). Екологічна ситуація території, що оточує парк, достатньо добра - на території селища відсутні заводи та серйозний антропогенний вплив на природне середовище.

Видовий склад деревних і чагарникових рослин оцінювали маршрутним методом і встановлювали види за визначником Д. Н. Доброчаєвої [9], а також [21], декоративні форми за [22], декоративні трав'янисті рослини за $[5,14]$. Висоту дерев встановлювали за допомогою 
оптичного висотоміра SuuntoPM-5/1520. Діаметр стовбура визначали на висоті 1,3 м за допомогою мірної вилки. Для оцінювання життєвого стану зелених насаджень використали 6-бальну шкалу В. А. Алєксєєва [2]. Розрахунок індексу стану деревостану парку за кількістю дерев виконували за формулою В. А. Алєксєєва [2]

$$
L_{n}=\frac{100 \cdot n_{1}+70 \cdot n_{2}+40 \cdot n_{3}+5 \cdot n_{4}}{N},
$$

де: $L_{n}-$ відносний життєвий стан деревостану; $n_{1}-$ кількість здорових, $n_{2}$ - ослаблених, $n_{3}-$ сильно ослаблених, $n_{4}$ - дерев, що відмирають; $N$ - загальна кількість дерев на пробній ділянці.

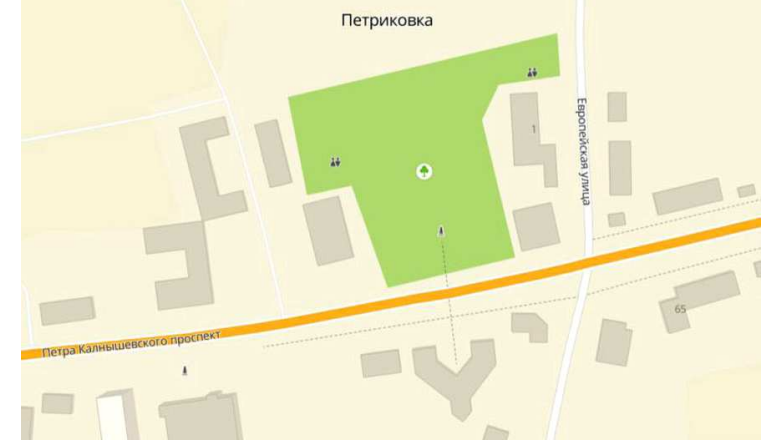

Рис. 1. Розташування парку на карті смт Петриківка / The location of the park on the map of Petrykivka

Найважливіші засоби ландшафтного дизайну та його популярні елементи враховували згідно з $[25,20]$.

Видове багатство дендрофлори розраховували за такою формулою:

$$
R=\frac{V-1}{\lg N},
$$

де: $V$ - кількість видів; $N$ - кількість особин.
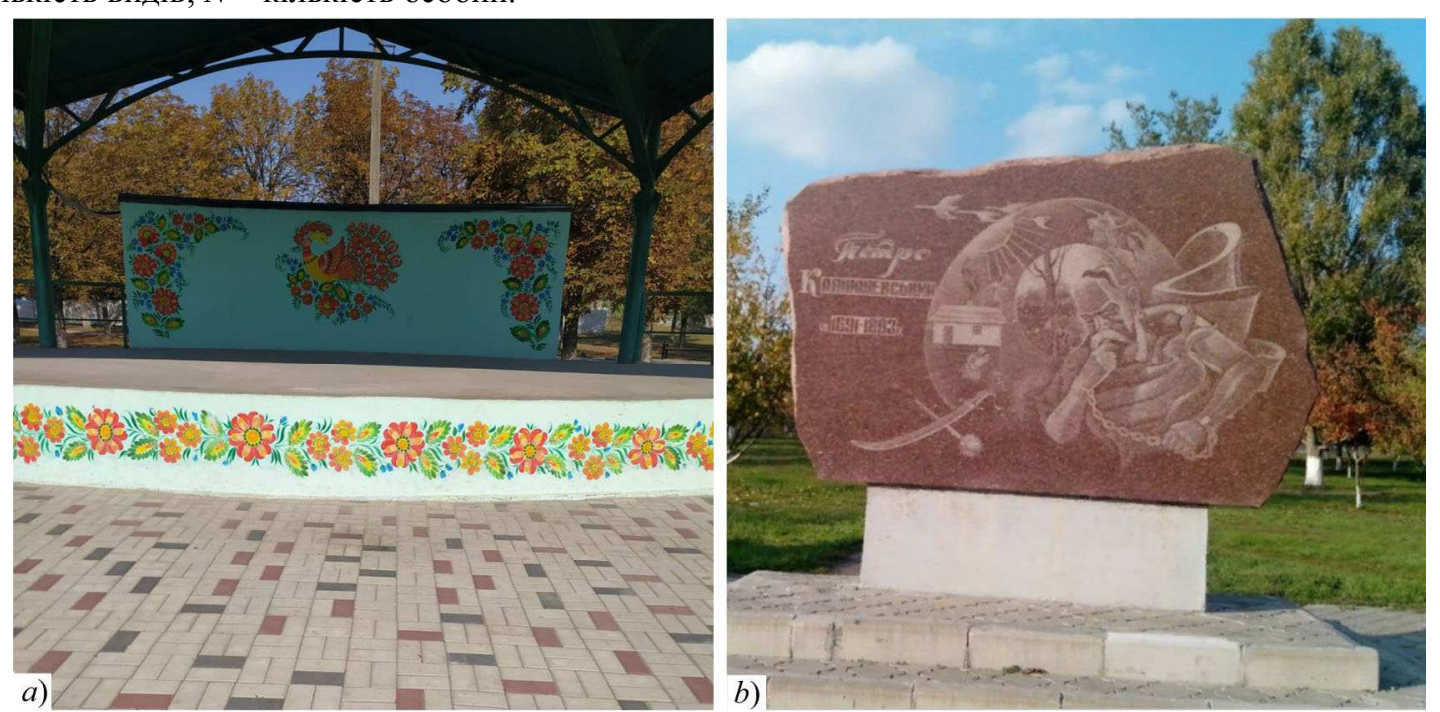

Рис. 2. Сцена у парку смт Петриківка / The scene in Petrykivka Park ( $a$ ); пам'ятна гранітна стела Петру Калнишевському /

The commemorative granite stele to Peter Kalnyshevsky $(b)$

Малі архітектурні форми - важливі засоби ландшафтного дизайну. У цьому парку вони представлені різними об'єктами. Привертає увагу альтанка традиційної форми із класичним дахом, що складається з металевих опуклих трикутників, зі шпилем на верхівці. По периметру альтанки на середньому рівні прикріплені металеві смуги, на яких розміщений петриківський орнамент.

Також у парку є дуже оригінальна мала архітектурна форма, яка нагадує усічену крашанку (рис. 3,a) 3

\section{Результати дослідження та їх обговорення / Research results and their discussion}

Парк смт Петриківка складається 3 декількох зон: активного відпочинку дітей (дитячий майданчик), зони фізкультурно-оздоровчих заходів, зони масових заходів, а також тихого відпочинку.

Дитячий майданчик добре оснащений ігровими елементами яскравих кольорів та деяким спортивним обладнанням, що враховує сучасні вимоги безпеки. До фізкультурно-оздоровчої зони належать невеликий майданчик зі столом для гри в настільний теніс, ділянка 3 двома столами для гри в шахи з виточеними ніжками, що нагадують шахові фігури.

Для масових заходів побудовано сцену, на якій у теплий період року на свята виступають артисти та гуртки самодіяльності. Сцена прикрашена петриківським розписом (рис. 2,a). Перед сценою розташований майданчик, викладений плиткою 3 кольоровим вкрапленням. Куточки для тихого відпочинку з лавами у затінку дерев можна побачити у декількох місцях парку. Головна прогулянкова алея обсаджена $з$ обох боків деревами.

Одним із планувальних елементів є доріжки. Вони забезпечують зручний прохід, візуально окреслюють функціональні зони, з'єднують певні ключові ділянки. У парку дорожньо-стежкова мережа добре розвинена. Доріжки мають тверде покриття, і вони викладені переважно плиткою, деякі щебенем.

Чималу роль у використанні засобів ландшафтного дизайну в організації простору відіграють елементи монументально декоративного мистецтва. У парку смт Петриківка $є$ пам'ятна гранітна стела Петру Калнишевському - останньому Кошовому отаману Запорізької Січі (рис. 2,b) та пам'ятні дошки.

трьома арками з різних боків із написами над ними: Biра, Надія, Любов. Споруда прикрашена петриківським розписом синього кольору з часткою зеленого. Всередині розпис більш різнобарвний.

У формуванні ландшафтної композиції застосована скульптура. На рис. $3, b$ показано архітектурний металевий кований букет (три квітки, три колоски) у петриківському стилі. Металева кована гірлянда квіток і листків Петриківського парку розташована на грунті (рис. 4). На завершенні цієї композиції вертикально під 
нахилом розміщений стилізований пензлик. До кованих виробів відносять і перила місточка.

Оригінальним рішенням у фольклорному стилі $\epsilon$ скульптура дівчинки - художниці, що створює картину петриківського живопису. Одяг дівчини прикрашений петриківськими візерунками (рис. 7). Півколом біля скульптури зростають кущі бузини чорної ф. 'Аспленіфолія' з розсіченими листками, що подібні на вайї папороті. 3 іншого боку гравійної доріжки розташований увігнутий півколом квітник із петунії гібридної з квітками білого та лілового кольорів.
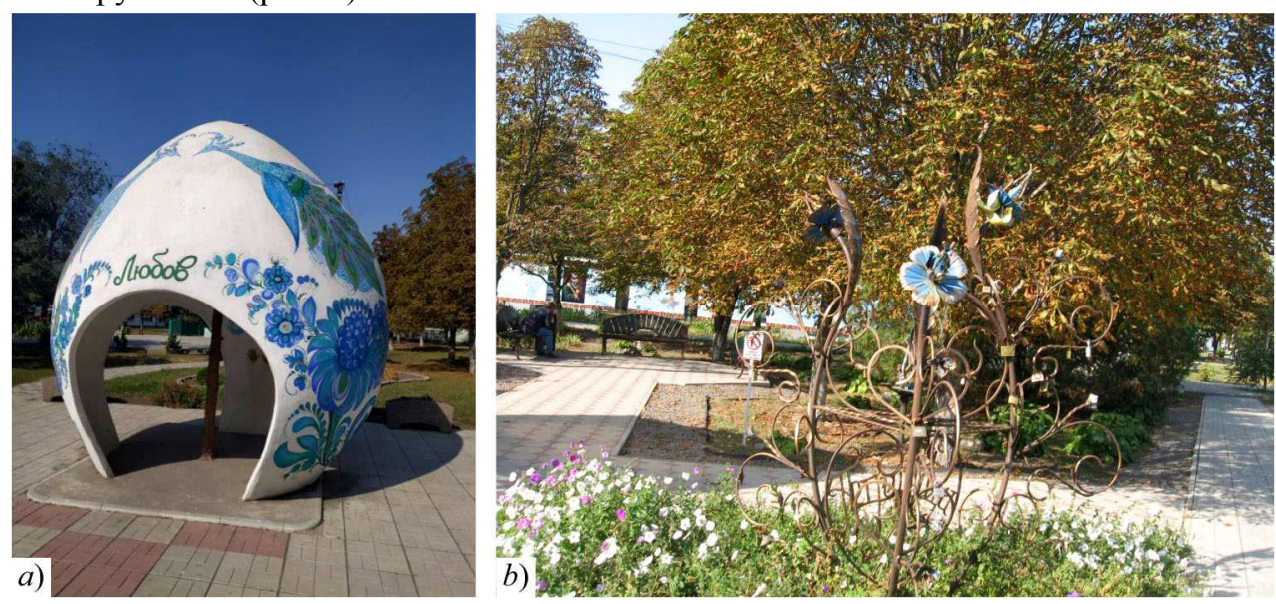

Рис. 3. Мала архітектурна форма у вигляді усіченої крашанки / The small architectural form in the shape of a truncated Easter egg (a); металевий кований букет / Metal forged bouquet $(b)$
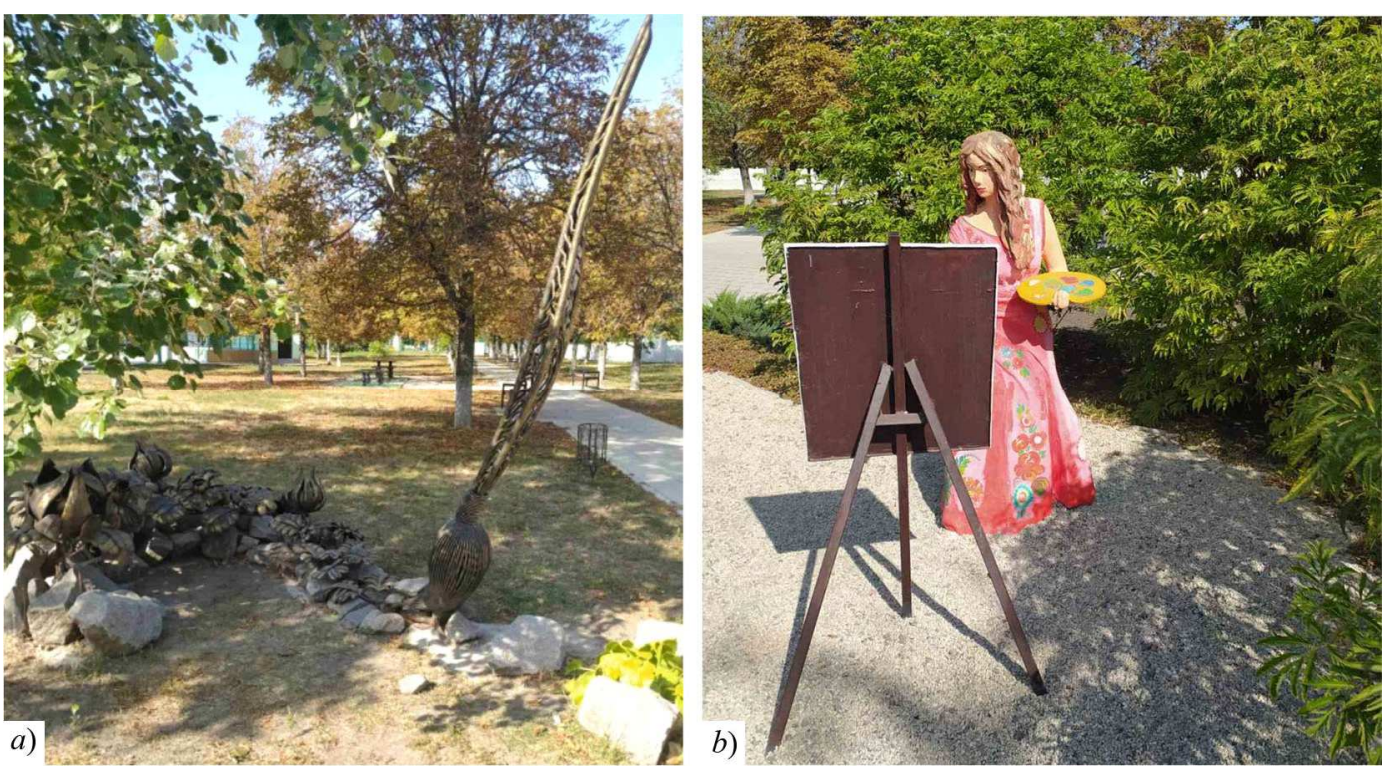

Рис. 4. Металева кована гірлянда квіток і листків / Metal wrought iron garland of flowers and leaves (a); скульптура художниці /

The sculpture of the female artist $(b)$

Вельми декоративним елементом ландшафтного дизайну парку є сухий ставок (рис. 8) зі звуженням на одному кінці. Він ілюструє втілення модних ідей Заходу у вітчизняному виконанні. Суха водойма імітує справжню. Вона оформлена декоративними злаковими рослинами - війником гостролистим, міскантусом китайським, кортадерією Селло тощо. Ці рослини, окрім імперати циліндричної, представлені 1-2 екземплярами. Декоративні трави парку смт Петриківка представлені 7ма родами та видами (табл. 1). Через звужену частину ставка перекинутий місток із декоративними перилами 3 металу. Реальність водоймі надають фігури двох лебедів. Варто зазначити, що не вистачає квітучого килима по "берегах" сухої водойми. Рекомендуємо висадити групи з лілійників жовтого, л. Міддендорфа, а також із сортів л. гібридного, півники гібридні, брунеру крупнолисту тощо.

У парку є невеликий класичний розарій. У ньому росте 41 садова троянда, переважно з групи чайно-гібридних. Виявлено три екземпляри із групи флорибунда, та дві рослини, що належать до групи плетистих троянд. Троянди висаджені без певної схеми. Палітра кольорів квіток - бордові, темно-пурпурні, червоні, рожеві, білі. Багато сучасних садоводів вважають нинішні розарії нудними, тому доповнюють їх іншими квітами.

Табл. 1. Декоративні трави (родина Злакові Poaceae Nash) парку смт Петриківка / Ornamental grasses (Poaceae Nash) of the Petrykivka Park

\begin{tabular}{|c|c|c|}
\hline $\begin{array}{c}\text { № } \\
\text { 3/п }\end{array}$ & Рід & Назва рослини \\
\hline 1 & Cortaderia Start & $\begin{array}{c}\text { Cortaderia selloana (Schult. \& Schult. } \\
\text { f.) Asch. \& Graebn. }\end{array}$ \\
\hline 2 & $\begin{array}{c}\text { Miscantus } \\
\text { Anderss }\end{array}$ & Miscanthus sinensis Andersson \\
\hline 3 & $\begin{array}{c}\text { Calamagrostis } \\
\text { Adans }\end{array}$ & Calamagrostis acutiflora (Schrad.) DC. \\
\hline 4 & Leumus Hoshst & Leymus arenarius (L.) Hochst. \\
\hline 5 & Pennisetum Rich & Pennisetum villosum R. Br. ex Fresen. \\
\hline 6 & Imperata Cirillo & Imperata cylindric (L.) Raeusch. \\
\hline 7 & Festuca L. & Festuca glauca Vill. \\
\hline
\end{tabular}

Scientific Bulletin of UNFU, 2021, vol. 31, no 4 


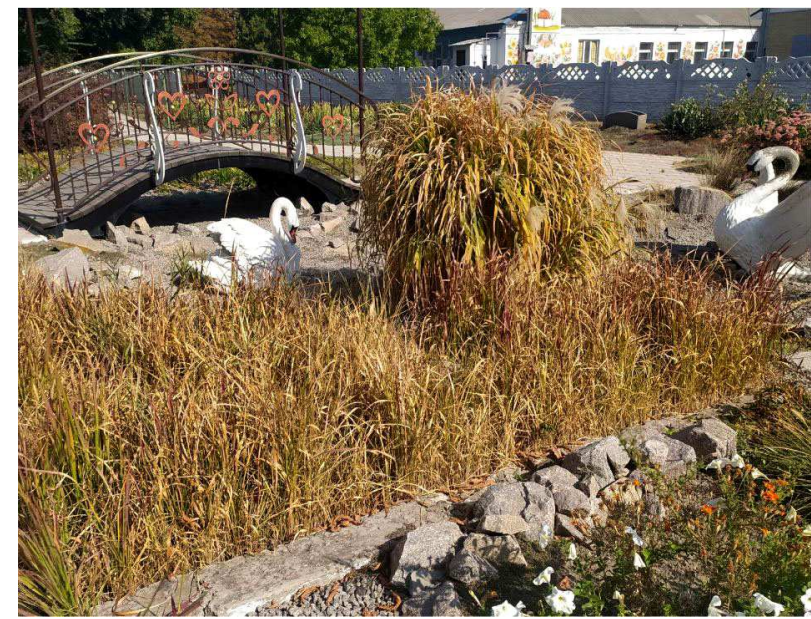

Рис. 5. Сухий ставок на території парку смт Петриківка /

Dry pond on the territory of Petrykivka Park

Партнером троянд у цьому розарії виступає петунія гібридна, яка цвіте весь сезон. Її кольорова гама біла, блідо-лілова, фіолетова. На те, що одним із гарних компаньйонів троянд у розарію $\epsilon$ петунія з квітами різного забарвлення, особливо з дрібними, вказує І. В. Клюєва [20]. Добре відтіняє квітучі троянди кущ ялівця скельного 'Скай Рокет', розташований у кінці розарію поруч із альтанкою. Оголені нижні частини стебел кущів троянд біля самого грунту прикриває бордюр із півників гібридних, що висаджені не тільки на передньому плані, але й оточують розарій із усіх боків.
Квітники - невід'ємний елемент парку. Вони мають великий емоційний вплив, створюють основні колоритні акценти. У цьому парку сформовані квітники серцеподібної, круглої, прямокутної, п'ятикутної, лопатевої форм. Вони представлені клумбами, міксбордерами, рабатками, стрічками.

На п'ятилопатевому квітнику, окрім квіткових рослин, росте сосна чорна 'Глобоза' на штамбах (2 шт.), два ялівці звичайні, барбарис Тунберга, на серцеподібному - ялівець козацький, туя західна 'Глобоза Нана' (2 шт.), верба козяча 'Пендула' (2 шт.).

Стрічка 3 канни індійської (рис. 5) обмежує з одного боку майданчик перед сценою. Рабатка 3 карликових півників та лілії ланцетолистої розташована перед пам'ятними дошками. Монохромні квітники створені 3 очитка видного у вигляді довгої рабатки і прямокутника, біхромні з петунії гібридної (білий та ліловий колір).

Використано і контейнерне озеленення. У 16 контейнерах висаджено хризантему корейську, яка має дуже непрезентабельний вигляд, ймовірно, через відсутність поливу, розташовані вздовж паркану зі східного боку парку. Треба зазначити, що у цьому парку, на відміну від інших селищних парків, висаджено досить багато багаторічних квіткових рослин - 15 таксонів, що належать до 10 родин. Найширше представлена родина Лілійні, до неї віднесено 5 видів рослин, Айстрові представлені трьома таксонами багаторічних рослин різних родів (табл. 2).

Табл. 2. Перелік квіткових рослин, що зростають у парку смт Петриківка /

The list of flowering plants growing in Petrykivka Park

\begin{tabular}{|c|c|c|c|c|}
\hline Родина & Рід & Назва рослин латинська & Назва рослин українська & $\begin{array}{c}\text { Кількість } \\
\text { рослин }\end{array}$ \\
\hline Асфоделові Asphodeloideae Burnett & Hemerocallis L. & Hemerocallis fulva (L.) L. & Лілійник рудуватий & Численні \\
\hline \multirow{5}{*}{ Лілійні Liliaceae Juss. } & Lilium L. & Lilium lancifolium Thunb. & Лілія ланцетолиста & 26 \\
\hline & Allium L. & Alium giganteum Regel & Цибуля гігантська & 27 \\
\hline & Tulipa L. & Tulipa hybrida Hort & Тюльпан гібридний & Численні \\
\hline & \multirow{2}{*}{ Hosta Tratt } & Hosta plantagenea Lam. (Asch.) & Хоста подорожникова & 24 \\
\hline & & Hosta lansifolia Engl. & Хоста ланцетолиста & 3 \\
\hline \multirow{2}{*}{ Півникові Iridaceae Juss. } & \multirow{2}{*}{ Iris L. } & Iris hybrida Hort. & Півники гібридні & 52 \\
\hline & & Iris pumila $\mathrm{L}$. & Півники карликові & 67 \\
\hline Каннові Cannaceae Juss. & Canna L. & Canna indica $\mathrm{L}$. & Канна індійська & 13 \\
\hline Ніктагінові Nictaginaceae Juss. & Mirabilis L. & Mirabilis jalapa L. & Мірабіліс ялапа & Численні \\
\hline Півонієві Paеoniaceae Rudol. & Paeonia L. & Paeonia chinensis hort. & Півонія китайська & 47 \\
\hline Жовтецеві Ranunculaceae Juss. & Aquilegia $\mathrm{L}$. & Aquilegia hybrida Hort. & Орлики гібридні & 4 \\
\hline Товстянкові Crassulaceae DC. & Sedum L. & Sedum spectabile Borean & Седум видний & 25 \\
\hline Пасльонові Solanaceae Juss. & Petunia Juss. & Petunia hybrida Vien. & Петунія гібридна & Численні \\
\hline \multirow{3}{*}{ Айстрові Asteraceae D. Dom } & Tagetes L. & Tagetes patula $\mathrm{L}$. & Чорнобривці відхилені & Численні \\
\hline & Coreopsis L. & Coreopsis tinctoria Nutt. & Кореопсис фарбувальний & 5 \\
\hline & Aster L. & Aster novi-belgii (L.) G. L. Nesom & Айстра новобельгійська & 3 \\
\hline Холодкові Asparagaceae Juss. & Yucca L. & Yucca filamentosa $\mathrm{L}$. & Юкка нитчаста & 4 \\
\hline
\end{tabular}

Серед багаторічників найчисельніші півники гібридні та карликові, півонія китайська, юка нитчаста. Канна індійська, яка зростає в парку, належить до багаторічних рослин, що не зимують у грунті. Різноманіття однорічних декоративних квітникових рослин невелике.

Грунтопокривні рослини презентовані чотирма таксонами, з яких 3 (седум їдкій, седум багатолистий і седум несправжній) належать до родини Товстянкові i один вид - барвінок малий - до родини Кутрові (табл. 3).

Значний внесок у створення мальовничих картин роблять кущі. Особливо декоративні калина звичайна, спірея японська, вейгела квітуча, барбарис Тунберга 'Атропурпуреа', які зростають групами або як солітери; живопліт вздовж паркана зі східного боку парку представлений сніжноягідником білим. Такі вічнозелені голонасінні рослини, як ялівець козацький, ялівець скельний 'Скай Рокет', туя західна 'Глобоза Нана', створюють певний колорит у всі сезони року.

Табл. 3. Грунтопокривні рослини у парку смт Петриківка / Ground cover plants in Petrykivka Park

\begin{tabular}{|c|c|c|}
\hline \multicolumn{2}{|c|}{ Рід } & Назва рослини \\
\hline \multirow{2}{*}{ Седум } & \multirow{2}{*}{$\begin{array}{c}\text { Se- } \\
\text { dum } \text { L. }\end{array}$} & Седум їдкий Sedum acre L. \\
\cline { 3 - 3 } & & Седум багатолистий Sedum dasyphyllum L. \\
\hline Барвінок & Vinca L. & Барвінок малий Vinca minor L. \\
\hline
\end{tabular}

Дерева у парку висаджені переважно рядами, хоча трапляються і групи. У парку зростає 31 вид деревних і 
кущових рослин, що належать до 14 родин (табл. 4). До родин Rosaceae віднесено 8 видів і форм, Cupressaceae та Sapindaceae - по 4. Усі інші родини представлені одним чи двома таксонами. Загальна кількість дерев і кущів становить 251 шт., із них дерев - 57,37\%, кущів $42,63 \%$.

Табл. 4. Таксономічний склад дендрофлори парку смт Петриківка / Taxonomic composition of dendroflora of Petrykivka Park

\begin{tabular}{|c|c|c|}
\hline \multicolumn{2}{|c|}{ Назва рослини } & \multirow{2}{*}{$\begin{array}{l}\text { Кіль- } \\
\text { кість }\end{array}$} \\
\hline українська & латинська & \\
\hline \multicolumn{3}{|c|}{ Соснові Pinaceae Lindl. } \\
\hline Сосна чорна 'Глобоза' & Pinus nigra J. F. Arn. 'Globosa' & 2 \\
\hline \multicolumn{3}{|c|}{ Кипарисові Cupressaceae F. Neger } \\
\hline Туя східна & Thuja orientalis Endl. & 2 \\
\hline Туя західна & Thuja occidentalis L. & 11 \\
\hline Ялівець козацький & Juniperus sabina L. & 10 \\
\hline $\begin{array}{c}\text { Ялівець скельний 'Скай } \\
\text { Рокет' }\end{array}$ & $\begin{array}{c}\text { Juniperus scopulorum 'Sky } \\
\text { Rocket' }\end{array}$ & 4 \\
\hline
\end{tabular}

\begin{tabular}{|l|l|l|}
\hline Барбарис Тунберга 'Aт- & Berberis thunbergii DC 'Atro- & 10
\end{tabular} ропупрпуреа' $\quad$ purpurea' Березові Betulaceae Gray

\begin{tabular}{|c|c|c|}
\hline \multicolumn{3}{|c|}{ Березові Betulaceae Gray } \\
\hline Береза повисла & Betula pendula Roth. & 4 \\
\hline \multicolumn{2}{|c|}{ Горіхові Juglandaceae Lindl. } \\
\hline Горіх грецький & Juglans regia L. & 4 \\
\hline \multicolumn{2}{|c|}{ В'язові Ulmaceae Mirb. } \\
\hline В'яз низький & Ulmus pumila L. & 4 \\
\hline В'яз граболистий & Ulmus carpinifolia Gled. & 3 \\
\hline \multicolumn{2}{|c|}{ Вербові Salicaceae Lindl. } \\
\hline
\end{tabular}

\begin{tabular}{|c|c|c|}
\hline Верба козяча 'Пендула' & \begin{tabular}{|c|} 
Salix caprea L. 'Pendula' Petz \\
et Kirchn.
\end{tabular} & 1 \\
\hline Тополя біла & Populus alba L. & 3 \\
\hline \multicolumn{3}{|c|}{ Мальвові Malvaceae Juss. } \\
\hline Липа серцелиста & Tilia cordata Mill. & 4 \\
\hline \multicolumn{3}{|c|}{ Кленові Aceraceae Lindl. } \\
\hline Клен гостролистий & Acer platanoides L. & 8 \\
\hline Клен ясенелистий & Acer negundo L. & 3 \\
\hline Клен татарський & Acer tataricum $\mathrm{L}$. & 3 \\
\hline
\end{tabular}

Гіркокаштанові Нypросаstanaceae Torr. et Gray

\begin{tabular}{|l|l|r|}
\hline Гіркокаштан звичайний & Aesculus hyppocastanum L. & 85 \\
\hline
\end{tabular} Бобові Fabaceae Lindl.

\begin{tabular}{|l|c|c|} 
Робінія звичайна & Robinia pseudoacacia L. & 10 \\
\hline \multicolumn{3}{|c|}{ Розові Rosaceae Juss }
\end{tabular}

\begin{tabular}{|c|c|c|}
\hline Спірея японська & Spirea japonica L. F. & 5 \\
\hline Пухироплідник калино- & Physocarpus opulifolius (L.) & 1
\end{tabular}

\begin{tabular}{|c|c|c|}
\hline $\begin{array}{c}\text { Пухироплідник калино- } \\
\text { листий }\end{array}$ & $\begin{array}{c}\text { Physocarpus opulifolius (L.) } \\
\text { Maxim }\end{array}$ & 1 \\
\hline \multicolumn{3}{|l|}{ Садові троянди } \\
\hline Чайногібридні & Hybrid tea & 31 \\
\hline Флорібунда & Floribunda & 8 \\
\hline Поліантові & Multiflora & 2 \\
\hline Черемха звичайна & Padus avium Mill. & 3 \\
\hline Черемха пізня & Padus serotina Agardh & 1 \\
\hline \multicolumn{3}{|c|}{ Гортензієві Hydrangeaceae Dumort. } \\
\hline Сніжноягідник білий & $\begin{array}{c}\text { Symphoricarpus albus (L.) } \\
\text { S. F. Blake }\end{array}$ & 9 \\
\hline Вейгела квітуча & Weigela florida $\mathrm{DC}$. & 1 \\
\hline \multicolumn{3}{|c|}{ Бузинові Sambucaceae Link. } \\
\hline $\begin{array}{c}\text { Бузина чорна 'Аспеніфо- } \\
\text { лія' } \\
\end{array}$ & $\begin{array}{c}\text { Sambucus nigra L. 'Aspenifo- } \\
\text { lia' }\end{array}$ & 4 \\
\hline \multicolumn{3}{|c|}{ Калинові Viburnaceae Dumort. } \\
\hline Калина звичайна & Viburnum opulus L. & 5 \\
\hline \multicolumn{3}{|c|}{ Маслинові Oleaceae Lindl. } \\
\hline Ясен звичайний & Fraxinus excelsior L. & 5 \\
\hline Бузок звичайний & Syringa vulgaris L. & 5 \\
\hline \multicolumn{2}{|r|}{ Всього } & 215 \\
\hline
\end{tabular}

Серед деревної рослинності найчисленнішими є гіркокаштан звичайний -85 шт. (59,03\% від загальної кількості деревних рослин). Робінія звичайна представлена 10 екземплярами $(6,94 \%)$, клен гостролистий -8 $(5,56 \%)$, кількість інших видів дерев становить 5 екземплярів і менше. У парку зростає тільки по одному екземпляру черемхи пізньої, верби козячої 'Пендула' та сосни чорної. Серед кущів (рис. 6) переважають сортові троянди різних груп, туя західна 'Глобоза' (11 шт.), ялівець козацький - 11 шт., барбарис Тунберга 'Атропурпуреа' - 10 шт., сніжноягідник білий - 9 шт. Чисельність інших кущів значно менша.

Обговорення результатів дослідження. За результатами інвентаризації насаджень парку смт Петриківка розраховано коефіцієнт видового різноманіття. Для цього рекреаційного об'єкта він дорівнює 12,5. Цей показник, порівняно з іншими дослідженими селищними парками Дніпропетровської області, є найбільшим. Так, для парку у с. Олександрівка він становить 7,7 [17], для парків у смт Магдалинівка та Іларіонове - 7,0 та 11,5, відповідно [6, 16].

У насадженнях парку найбільшу кількість дерев віднесено до таких класів діаметрів: $24-28 \mathrm{~cm}-25,17 \%$, 28-32 см - 22,34 \% (табл. 6). Мало відрізняються за кількістю рослин групи з діаметрами в межах 16-20 м і 20-24 м - 13,98 й 16,78 \% відповідно від загальної кількості дерев. У цих класах діаметрів найбільше дерев гіркокаштана звичайного.

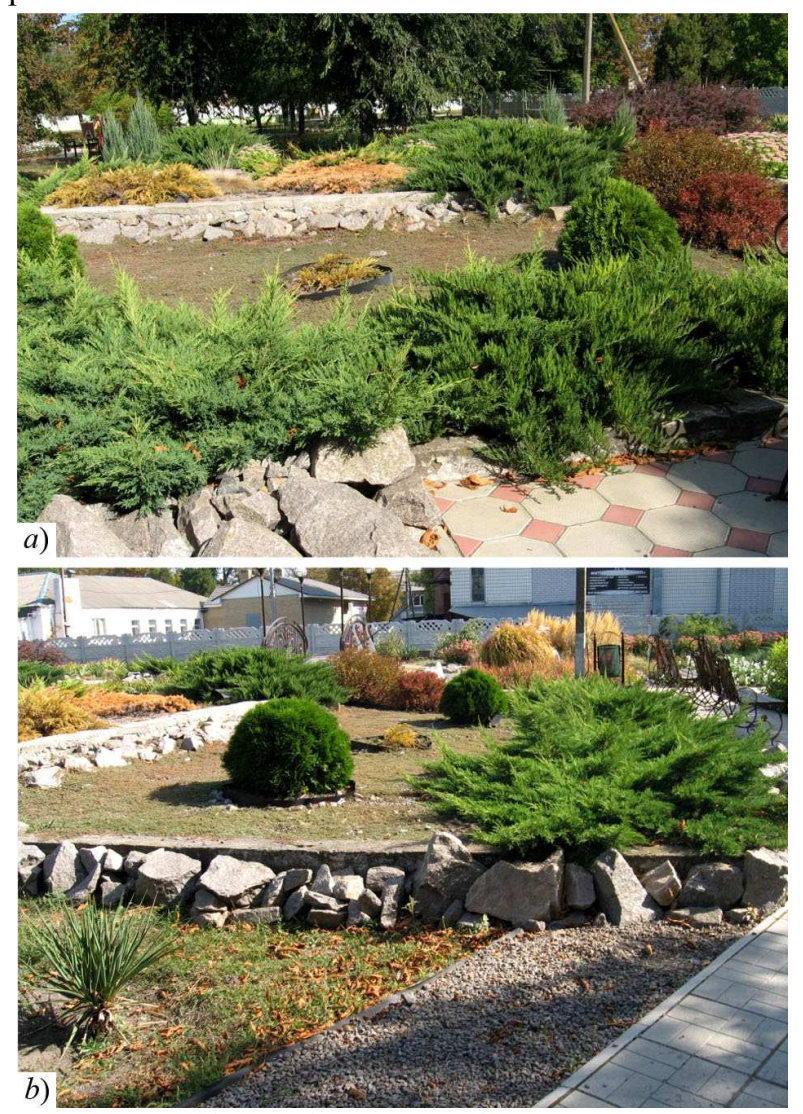

Рис. 6. Композиції з кущів на території парку смт Петриківка / Compositions from the bushes on the territory of Petrykivka Park

До дерев із найбільшим діаметром 32,1-36 см у парку належить гіркокаштан звичайний - 2 шт. і по одному екземпляру тополі білої та в'яза низького. Розміри діаметрів до 4 см виявлено у 4 дерев: горіха грецького, сосни чорної карликової, верби козячої 'Пендула'. 
Табл. 5. Розподіл деревних рослин парку смт Петриківка за діаметром, см / Distribution of woody plants in Petrykivka Park by diameter, $\mathrm{cm}$

\begin{tabular}{|c|c|c|c|c|c|c|c|c|c|}
\hline \multirow{2}{*}{ Латинська назва } & \multicolumn{7}{|c|}{ Ступінь товщини } & \multicolumn{2}{c|}{ Всього } \\
\cline { 2 - 10 } & $4,0-8,0$ & $8,1-12,0$ & $12,01-16,0$ & $16,1-20,0$ & $20,1-24,0$ & $24,1-28,0$ & $28,1-32,0$ & $32,1-36,0$ & - \\
\hline Pinus nigra J. F. Arn. & 2 & - & - & - & - & - & - & 2 \\
\hline Salix caprea L. & 1 & - & - & - & - & - & - & - & 1 \\
\hline Betula pendula Roth. & - & 1 & - & 3 & - & - & - & - & 4 \\
\hline Juglans regia L. & 4 & - & - & - & - & - & - & - & 4 \\
\hline Ulmus pumila L. & - & - & - & 1 & 1 & - & 1 & 1 & 4 \\
\hline Ulmus carpinifolia Gled. & - & - & - & - & 1 & 2 & - & - & 3 \\
\hline Populus alba L. & - & - & - & - & 1 & 1 & - & 1 & 3 \\
\hline Tilia cordata Mill. & - & - & - & 1 & 1 & 2 & - & - & 4 \\
\hline Padus avium Agardh & - & 3 & - & - & - & - & - & - & 3 \\
\hline Padus serotina L. & - & 1 & - & - & - & - & - & - & 1 \\
\hline Robinia pseudoacacia L. & - & - & 3 & - & 3 & 3 & 1 & - & 10 \\
\hline Acer platanoides L. & - & - & 1 & 2 & 1 & 3 & 1 & - & 8 \\
\hline Acer negundo L. & - & - & - & 1 & 1 & - & 1 & - & 3 \\
\hline Acer tataricum L. & 1 & 2 & - & - & - & - & - & - & 3 \\
\hline Aesculus hyppocastanum L. & - & 1 & 4 & 12 & 14 & 24 & 28 & 2 & 85 \\
\hline Fraxinus excelsior L. & - & 1 & 2 & - & 1 & 1 & - & - & 5 \\
\hline Bcього, шт. & 8 & 9 & 10 & 20 & 24 & 36 & 32 & 4 & 143 \\
\hline \% & 5,59 & 6,29 & 6,99 & 13,98 & 16,78 & 25,17 & 22,34 & 2,79 & 100 \\
\hline
\end{tabular}

Табл. 6. Розподіл дерев парку за висотами, м / Distribution of trees in Petrykivka Park beyond the heights, $\mathrm{m}$

\begin{tabular}{|c|c|c|c|c|c|c|c|}
\hline \multirow{2}{*}{ Латинська назва } & \multicolumn{6}{|c|}{ Висота дерева } & \multirow{2}{*}{ Всього } \\
\hline & до 4 & $4,1-6,0$ & $6,1-8,0$ & $8,1-10,0$ & $10,1-12,0$ & $12,1-14,0$ & \\
\hline Pinus nigra J. F. Arn. & 2 & - & - & - & - & - & 2 \\
\hline Betula pendula Roth. & - & 4 & - & - & - & - & 4 \\
\hline Juglans regia L. & 4 & - & - & - & - & - & 4 \\
\hline Ulmus pumila $\mathrm{L}$. & - & - & 1 & 2 & 1 & - & 4 \\
\hline Ulmus carpinifolia Gled. & - & - & - & 1 & 1 & 1 & 3 \\
\hline Salix caprea L. & 1 & - & - & - & - & - & 1 \\
\hline Populus alba L. & - & - & 1 & 2 & - & - & 3 \\
\hline Tilia cordata Mill. & - & - & 3 & 1 & - & - & 4 \\
\hline Padus avium Agardh & - & 1 & - & - & - & - & 1 \\
\hline Robinia pseudoacacia L. & - & 2 & 5 & 3 & - & - & 10 \\
\hline Acer platanoides L. & - & 1 & 5 & 2 & - & - & 8 \\
\hline Acer negundo L. & - & 2 & 1 & - & - & - & 3 \\
\hline Acer tataricum $\mathrm{L}$. & 1 & 2 & - & - & - & - & 3 \\
\hline Aesculus hyppocastanum L. & 1 & 31 & 53 & - & - & - & 85 \\
\hline Fraxinus excelsior $\mathrm{L}$. & - & 4 & 1 & - & - & - & 5 \\
\hline Всього, шт. & 9 & 50 & 70 & 11 & 2 & 1 & 143 \\
\hline$\%$ & 6,29 & 34,96 & 48,95 & 7,69 & 1,39 & 0,69 & 100 \\
\hline
\end{tabular}

Розподіл дерев за висотою свідчить, що їх максимальну кількість віднесено до класу висот 6,1-8,0 м $48,95 \%$ та 4,1-6,0 м - 34,96\% (табл. 6). У цих класах переважає гіркокаштан звичайний, оскільки, як вже відомо, це панівна порода у парку. До найнижчих відносять дерева на штамбі - верба козяча, а також екземпляри гіркокаштана звичайного, які були висаджені порівняно недавно. До класу найвищих дерев - 12,1-14 м входить один екземпляр в'яза граболистого, і два дерева в'яза граболистого і в'яза низького, що мають висоту в межах 10,1-12 м.

У загальній привабливості ландшафту значущу роль відіграє добрий загальний вигляд деревних рослин. Оцінювання життєвого стану насаджень у парку показало, що 80,5 \% віднесено до першої категорії (без ознак ослаблення), 16,3\% - до другої категорії (помірно ослаблені) і тільки 3,2\% - до третьої категорії (середньо ослаблені). Індекс життєвого стану деревостану парку становить 93,18, тобто оцінюють як "здоровий".

Варто зазначити, що хоча в другій половині вегетації листки гіркокаштана звичайного і вражені каштановою міллю, вони ще й у вересні зберігають певну декоративність, сухих гілок на деревах немає. Проте ці де- рева краще поступово замінювати іншими видами. Чимало дерев має викривлення стовбурів, багатостовбурність, у невеликих кількостях трапляються механічні ушкодження та морозобоїни. Багатостовбурність частіше трапляється у гіркокаштана звичайного.

У гіршому стані перебувають молоді кущі. У деяких iз них повсихала частина листків і верхівки пагонів (барбарис Тунберга, спірея японська, туя західна 'Глобоза'). На території парку також розташовані дві галявини позбавлені будь-якої рослинності, їх трав'яний покрив складається 3 пожухлої трави. Загалом ці галявини мають недекоративний вид. Це можна пояснити дуже сухими спекотними погодними умовами у період вегетації рослини і відсутністю поливу, що свідчить про погану адаптованість трав'янистих рослин цих видів до нестачі вологи.

\section{Висновки / Conclusions}

1. У парку смт Петриківка міститься багато різноманітних малих архітектурних форм - сцена із традиційним для селища розписом, звичайні та ковані скульптури, альтанка, місток тощо, що пропагують мистецтво петриківського розпису. 
2. Декоративні трави парку представлені 7 родами та видами, квіткові багаторічні рослини - 13 родами та 15 таксонами, однорічники - 3 родами та таксонами, а грунтопокривні рослини - 2 родами та 4 таксонами. Серед багаторічників найчисельнішими $є$ півники гібридні та карликові, півонія китайська, юкка нитчаста. На території парку створено невеликий класичний розарій. Квітники представлені клумбами, міксбордерами, рабатками, стрічками.

3. У парку зростає 31 вид деревно-кущових рослин, що входять до 14 родин. Загальна кількість дерев і кущів становить 251 шт., із них дерев - 57,37\%, кущів $42,63 \%$. 3 деревної рослинності найчисленнішими $€$ гіркокаштан звичайний - 85 шт. (59,03 \% від загальної кількості деревних рослин). Серед кущів кількісно переважають садові троянди, туя західна 'Глобоза', ялівець козацький, барбарис Тунберга 'Атропупрпуреа', сніжноягідник білий. Коефіцієнт видового різноманіття парку дорівнює 12,5, що більше, ніж в інших досліджених парках Дніпропетровської області.

4. У насадженнях парку найбільша кількість дерев таких класів діаметрів: 24-28 см, 28-32 см - 25,17 та 22,34 \%, відповідно, від загальної кількості дерев. Найчисельніше у цих групах представлений гіркокаштан звичайний. Розподіл дерев за висотою показав, що їх максимальну кількість віднесено до класу висот 6,1-8,0 м - 48,95\% та 4,1-6,0 м - 34,96\%. У цих класах переважає гіркокаштан звичайний, оскільки це панівна порода у парку.

5. Оцінювання життєвого стану насаджень у парку показало, що 80,5 \% деревних і кущових рослин віднесено до першої категорії (без ознак ослаблення), 16,3 \% - до другої категорії (помірно ослаблені) і тільки 3,2 \% до третьої категорії (середнього ослаблені). Індекс життєвого стану деревостану парку становить 93,18 та оцінюють як "здоровий".

3 урахуванням виконаного аналізу ландшафтного дизайну, стану деревних рослин, наявності вільних недоглянутих ділянок пропонуємо рекомендації 3 реконструкції окремих ділянок парку смт Петриківка, зокрема: доповнити асортимент декоративних трав'янистих рослин однорічниками, посадити навколо сухого ставка різні види лілійників, півники гібридні, брунеру крупнолисту та інші. У парку пропонуємо використовувати ранньоквітучі цибулинні рослин для покращення естетичного вигляду насаджень. Потрібно замінити травостій низької якості на декоративний та стійкий для степової зони газон. На одній з ділянок парку доцільно створити високу яскраву гірку з декоративного каміння та багаторічних трав'янистих рослин (геліхризум тяньшанський, тирлич даурський, гвоздика-трав'янка, дицентра гарна, півник злаковий та п. карликовий тощо), кущів (барбарис Тунберга 'Нана', спірея японська, ялівець китайський). Також необхідно покращити догляд за контейнерними рослинами.

\section{References}

1. Agalceva, V. A. (2008). Fundamentals of forestry. Moscow: GOU VPO MGUL, 213 p. [In Russian].

2. Alekseev, V. A. (1989). Diagnostics of the vital state of trees and tree stand. Russian Journal of Forest Science, 4, 51-57. [In Russian].

3. Arhipova, E. A. (2018). Phytocenotic composition and structure of forest vegetation in the "Khvalynsky" National Park. Saratov: Alierit, 164 p. [In Russian].

4. Avdeeva, E. V. (2004). Landscape environment as the basis for sustainable development of urbanized areas. Strategy of social and economic development of Krasnoyarsk cit. Krasnoyarsk, 245-247. [In Russian].
5. Bessonova, V. P. (2010). Flower garden plants. Directory. Dnipropetrovsk: Svidler A. L., $175 \mathrm{p}$.

6. Bessonova, V. P., \& Ivanchenko, O. E. (2020). Species richness of dendroflora and aesthetic assessment of phytocenoses of the park of Mahdalynivka town. Scientific Bulletin of UNFU, 30(1), 25-32. [In Ukrainian].

7. Bulanova, M. B., \& Ugrehelidze, E. A. (2015). Park in the cultural environment of the city. News of Russian State University for the Humanities. Philosophy. Sociology. Art history, 96-99. [In Russian].

8. Bykov, V. A., Zhuchenko, A. A., Rabinovich, A. M., Bateha, T. I., Orlova, E. V., \& Dubovickaja, O. Ju. (2000). Complex environment-forming phytotechnologies of the 21st century. Medicinal plant growing. Collection of scientific papers; $2^{\text {nd }}$ publishing, 148-155. [In Russian].

9. Dobrochaeva, D., Kotov, M., Prokudin, Ju., \& Barbarich, A. (1999). The determinant of higher plants of Ukraine (2nd ed.). Kiev: Fitosociocentr, 548 p. [In Russian].

10. Dubovitskaya, O. Y., \& Zolotareva, E. V. (2014). Ornamental deciduous and coniferous woody plants for arrangement of green spaces in cities and towns of Orel region. Belgorod State University Scientific Bulletin, 23(194), 29, 38-43. [In Russian].

11. Dubovitskaya, O. Yu., \& Masalova, L. I. (2013). Prospects for expanding sustainable range of woody plants for landscape construction using exotic species of North. Contemporary horticulture. Electronic Journa, 4, 1-12. [In Russian].

12. Dudyn, R. B. (2000). Phytocenotic structure of the park. I. Franko. Scientific Bulletin of UNFU, 9(8), 50-53. [In Ukrainian].

13. Erzin, I. V. (2011). Assessment of the state of plantings in city parks in connection with their reconstruction (on the example of Moscow). Abstract of Candidate Dissertation for Biology Sciences (Ecology 03.02.08), Moscow: Nauka, 20 p. [In Russian].

14. Golovkin, B. N., Kitaeva, L. A., \& Nemchenko, Je. P. (1986). Ornamental plants of the USSR. Moscow: Mysl, 320 p. [In Russian].

15. Goranova, O. A., Atroshhenko, L. A., \& Bykova, M. V. (2017). Comprehensive improvement of urban areas in Moscow. Landscaping of improvement objects. Moscow: MSU. 244 p. [In Russian].

16. Ivanchenko, O. E., \& Bessonova, V. P. (2020). Species diversity and aesthetic characteristics of the planting of the settlement park (urban-type settlement Ilarionove). Issues of steppe forestry and forest reclamation of soils, 49, 26-47. [In Ukrainian].

17. Ivanchenko, O., \& Bessonova, V. (2015). Phytosanitary condition of the dendroflora of the memorial park named after V. M. Komarov Oleksandrivka village, Dnipropetrovsk region. Ecology and nature management in the system of optimization of relations between nature and society: Materials of the $2^{d}$ International Scientific and Practical Internet Conference (Ternopil, 19-20 March 2015). Ternopil, 73-74. [In Ukrainian].

18. Kaspruk, O. I. (2006). An assortment decorativity of treesand bushes in Lviv ancient parks. Scientific Bulletin of UNFU, 16(4), 222-226. [In Ukrainian].

19. Klimovich, L., Efimenko, V., \& Mitin, N. (2014). The peculiarities of landscape planting the organization of the park of the Grodno forestry. Actual problems of the forestry complex. Bryansk, 38, 175-179. [In Russian].

20. Kljuva, I. V. (2010). Landscape design. Kharkov: Vesta, 160 p. [In Russian].

21. Kohno, N. A. (1986). Trees and shrubs cultivated in the Ukrainian SSR. Angiospermae. Kiev: Nauk. dumka, 720 p. [In Russian].

22. Kolesnikov, A. I. (1958). Decorative forms of tree species. Moscow: Ministry of Public Utilities of the RSFSR, 271 p. [In Russian].

23. Kolyada, E. M. (2010). The Formation History and Typological Peculiarities of Gardens and Special Purpose Parks. I. Yakovlev Chuvash State Pedagogical University Bulletin, 5, 296-304. [In Russian].

24. Kostina, A. A., \& Tereshina, O. B. (2018). Features of urban multifunctional parks design. Architecture, urbanism \& design, 16, 2 8. [In Russian].

25. Krizhanovskaja, N. Ja. (2002). The basics of landscape design. Harkov: HGAGH, 204 p.

26. Kucheryavyy, V. P. (2003). Phytomelioration. Lviv: Svit, 540 p. [In Ukrainian]. 
27. Kucheryavyy, V. P. (2005). Landscaping of populated areas. Lviv: Svit. 454 p. [In Ukrainian].

28. Kucheryavyy, V. P. (2008). Lviv gardens and parks. Lviv: Svit, 360 p. [In Ukrainian].

29. Kucheryavyy, V. P., \& Gorunets, K. S. (2010). Phytocoenotic structure of green plantations of forest park in the XIX century in Bruhovychi. Scientific Bulletin of UNFU, 20(8), 8-11. Retrieved from: https://nv.nltu.edu.ua/Archive/2010/20_8/8_Kuczeriawyj_ 20_8.pdf. [In Russian].

30. Markov, F. F. (2015). Current state of parks, monuments of landscape art, of Zhitomir region (Ukraine). Izvestia Sankt-Peterburgskoj Lesotehniceskoj Akademii, 210, 47-57. [In Russian].

31. Marno-Kutsa, O. (2016). Green areas of settlements Cherkassy region: current state and development prospects. Abstract of Candidate Dissertation for Agricultural Sciences, Lviv, 20 p. [In Ukrainian].

32. Melnichenko, O. N., \& Berezko, O. M. (2012). Peculiarities of compositions of Belarusian landscape objects with exposition zones. Proceedinga of BSTU. Forestry. Environmental management. Reprocessing of renewable resources, 1, 249-252. [In Russian].

33. Mihajlov, S. M. (2011). The design of a modern city is a complex organization of the subject-spatial environment (theoretical and methodological concept). Abstract of Doctoral Dissertation of art history sciences (Art history 17.00.06), Moscow: Nauka, 57 p. [In Russian].

34. Muracheva, L. S., Bedareva, O. M., \& Hljustov, V. K. (2013). Monitoring of ecosystems in urbanized areas of Kaliningrad region. Monograph. Kaliningrad: FGBOU VPO "KGTU", 250 p. [In Russian].

35. Nefedov, V. A. (2002). Landscaping and environmental sustainability. SPb: Polygraphist, 295 p. [In Russian].

36. Oleksiichenko, N. O., Pidkhovna, S. M. (2008). Retrospective analysis of the park-monuments of landscape architecture of Ternopil region. Scientific Bulletin of UNFU, 29(5), 17-21. https://doi.org/10.15421/40290503
37. Prohorenko, N. B., \& Usmanova, N. R. (2018). Phytocenotic diversity and environmental estimation of park vegetation in Kazan. Ecology and geography of plant communities. Yekaterinburg: Ural Federal University Research Portal, 760-764. [In Russian].

38. Ramazanova, Ju. R. (2011). Phytocenotic studies as an important pre-project stage in the reconstruction of parks. Forestry Bulletin, 4, 167-169. [In Russian].

39. Rogovskiy, S. V. (2018). Analysis of structure and condition of the dendroflora of Kryukovshchina park in Kiev-Svyatoshyn district, Kyiv region. Agrobiology, 2, 79-89. [In Ukrainian].

40. Rogovsky, S. V. (2008). Classification of Measures, Applied for Landscape Design in Rural. Scientific Bulletin of UNFU, 18(7), 140-145. [In Ukrainian].

41. Shlapak, V. P., Kodzhebash, A. V., Kozachenko, I. V., Parubok, M. I., \& Maslovata S. A. (2016). Assessment of current situation of the park in Ivanivka village of Uman district and the project of its reconstruction. Scientific Bulletin of UNFU, 28(6), 47-51. https://doi.org/10.15421/40280609

42. Suslova, Ye. P., Polyakov, A. K., \& Kharkhota, L. V. (2013). Woody plants condition in the park stands of the industrial cities in the South-east of Ukraine. Industrial botany, 13, 109-115. [In Ukrainian].

43. Suslova, Ye. P., Zadorozhna, D. V., \& Harhota, L. V. (2014). The variety and condition of tree plantations in the park named after A. P. Chekhov of Khartsyzk city (Donetsk region). News of Dnipropetrovsk State Agrarian and Economic University, 1(33), 2831. [In Ukrainian].

44. Syplova, N. O. (2009). Structural analysis of rare dendroflora in parks of Vinnytsia region. Scientific Bulletin of UNFU, 19(5), 3942. [In Ukrainian].

45. Sysak, V. O., \& Barmashyna, L. M. (2013). Problems of the development of the park system of Ukraine. Architectural bulletin of Kyiv National University of Construction and Architecture, 1, 200-212. [In Ukrainian].

V. P. Bessonova, O. E. Ivanchenko

Dnipro State Agrarian and Economic University, Dnipro, Ukraine

\section{DESIGN SOLUTIONS AND SPECIES COMPOSITION OF PLANTS OF THE PARK IN PETRYKIVKA URBAN-TYPE SETTLEMENT, DNIPROPETROVSK REGION}

The landscape organization of Petrykivka urban-type settlement park and the existing assortment of decorative herbaceous, tree and shrub plants have been investigated, the taxation and life characteristics of the latter have been evaluated in the research presented. The territory of the park has a pronounced zoning and consists of a playground, a zone of health and fitness, mass events and quiet recreation. There are elements of monumental decorative art in the park, such as a stele to the last commander of Cossack camp P. Kalnyshevskyi, some small architectural forms like a truncated Easter egg, a landscape gardening sculpture - a female artist, a wrought-iron bouquet and a garland, as well as other elements of landscape design, e.g., a dry pond. The flower decoration of the park is represented by flower beds, mixborders, ridges, and ribbons. The range of flowering plants consists of annuals and perennials, and these are garden roses, Petunia hybrida, Iris hybrida, Canna indica, Sedum spectabile, Paeonia chinensis hort. Container gardening with Chrysanthemum $\times$ koreanum was also used. Different types of Sedum and Vinca minor were used from ground cover plants. Viburnum opulus, Spiraea japonica, Berberis thunbergii, Weigela florida, various species of Juniperus, Thuja orientalis and Thuja occidentalis grow from shrubs in the park, which form groups or act as single specimen sets. In total, 31 species of woody and shrub plants, belonging to 14 families, grow in the park. Their total number is 251 . Aesculus hyppocastanum prevails in tree plantations ( $59.03 \%$ of all plants). The quantitative representation of other taxons is 10 or less specimens. By the diameter of the trunk in the plantations, the most abundant are trees that belong to the classes $24-28$ and $28-32 \mathrm{~cm}-25.17$ and $22.34 \%$ of their total number. These groups are dominated by Aesculus hyppocastanum as the most abundant species in the park. About half of the trees in the park have height from 6.1 to $8.0 \mathrm{~m}$. $34.96 \%$ of trees are characterized by a lower height (4.1-6.0 m). $80.5 \%$ of woody plants grow without signs of damage in the park of Petrykivka urban-type settlement, 16.3 and $3.2 \%$ are moderately weakened. According to the vital state index, the stand is assessed as "healthy".

Keywords: rural park; landscape design of the territory; flower decoration; woody plants; taxation characteristics; vital state. 